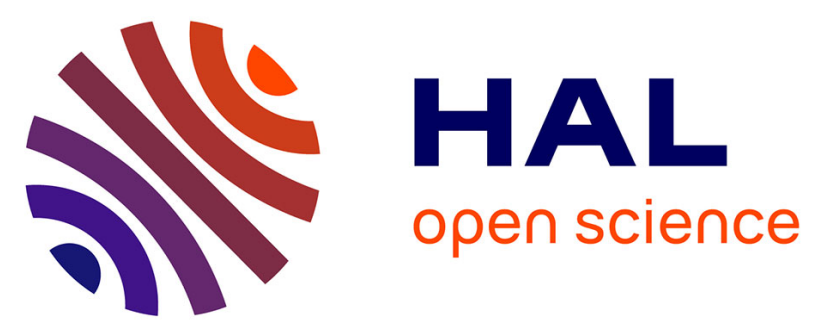

\title{
Increased adrenal responsiveness and delayed hatching date in relation to polychlorinated biphenyl exposure in Arctic-breeding black-legged kittiwakes (Rissa tridactyla)
}

Sabrina Tartu, Adam Lendvai, Pierre Blévin, Dorte Herzke, Paco Bustamante, Børge Moe, Geir Wing Gabrielsen, Jan Ove Bustnes, Olivier Chastel

\section{To cite this version:}

Sabrina Tartu, Adam Lendvai, Pierre Blévin, Dorte Herzke, Paco Bustamante, et al.. Increased adrenal responsiveness and delayed hatching date in relation to polychlorinated biphenyl exposure in Arctic-breeding black-legged kittiwakes (Rissa tridactyla). General and Comparative Endocrinology, 2015, 219, pp.165-172. 10.1016/j.ygcen.2014.12.018 . hal-01217081

\section{HAL Id: hal-01217081 \\ https://hal.science/hal-01217081}

Submitted on 20 Oct 2015

HAL is a multi-disciplinary open access archive for the deposit and dissemination of scientific research documents, whether they are published or not. The documents may come from teaching and research institutions in France or abroad, or from public or private research centers.
L'archive ouverte pluridisciplinaire HAL, est destinée au dépôt et à la diffusion de documents scientifiques de niveau recherche, publiés ou non, émanant des établissements d'enseignement et de recherche français ou étrangers, des laboratoires publics ou privés. 


\section{Increased adrenal responsiveness and delayed hatching}

\section{date in relation to polychlorinated biphenyl exposure in}

\section{Arctic-breeding black-legged kittiwakes (Rissa tridactyla)}

Sabrina Tartu ${ }^{1}$, Adam Lendvai ${ }^{2}$, Pierre Blévin ${ }^{1}$, Dorte Herzke ${ }^{3}$, Paco Bustamante ${ }^{4}$, Børge Moe ${ }^{5}$, Geir Wing Gabrielsen ${ }^{6}$, Jan Ove Bustnes ${ }^{5}$ and Olivier Chastel $^{1}$

${ }^{1}$ Centre d'Etudes Biologiques de Chizé (CEBC), UMR 7372-ULR CNRS, F-79360, France

${ }^{2}$ Department of Evolutionary Zoology, University of Debrecen, Egyetem tér 1, H-4032 Debrecen, Hungary

${ }^{3}$ Norwegian Polar Research Institute, FRAM Centre High North Research on Climate and the Environment N-9296 Troms $\phi$, Norway

${ }^{4}$ Littoral Environnement et Sociétés (LIENSs), UMR 7266 CNRS-Université de la Rochelle, 2 rue Olympe de Gouges 17000 La Rochelle, France

${ }^{5}$ Norwegian Institute for Nature Research, FRAM - High North Research Centre on Climate and the Environment, N-9296 Troms $\varnothing$, Norway

${ }^{6}$ Norwegian Institute for Air Research, FRAM - High North Research Centre on Climate and the Environment, N-9296 Troms $\phi$, Norway

*tartu.sabrina@gmail.com 
Abstract: High levels of environmental contaminants such as polychlorinated biphenyls (PCBs), organochlorine pesticides (OCPs) and mercury (Hg) have been reported in some Arctic top predators such as seabirds. Chronic exposure to these contaminants might alter the response to environmental changes through interference with the regulation of corticosterone (CORT), a glucocorticoid stress hormone released by the hypothalamo-pituitary-adrenal (HPA) axis. Positive and negative relationships between CORT and environmental contaminants have been reported in polar seabirds. However, patterns appear inconclusive and it is difficult to attribute these relationships to a dysfunction of the HPA axis or to other confounding effects. In order to explore the relationships between the HPA axis activity and contaminants, we tested whether different aspects of the HPA axis of an Arctic seabird, the black-legged kittiwakes Rissa tridactyla, would be related to blood $\mathrm{Hg}$, PCB and OCP concentrations. Male kittiwakes were caught during the incubation period in Svalbard and were subjected to different stress series: (1) a capture-restraint stress protocol, (2) an injection of dexamethasone (DEX) that enabled to test the efficacy of the HPA negative feedback and (3) an injection of adrenocorticotropic hormone (ACTH) that informed on the adrenal responsiveness. The HPA axis activity was unrelated to $\sum$ OCPs and $\mathrm{Hg}$. However, birds with high concentrations of $\sum$ PCBs released more CORT after the ACTH injection. It is suggested that $\sum$ PCBs may increase the number of ACTH-receptors on the adrenals. Additionally, hatching date was delayed in males with higher concentrations of $\sum$ PCBs and $\sum$ OCPs. This study gives new evidence that PCBs and adrenal activity may be related. Thus high PCB burden may make individuals more prone to other stressors such as ongoing climate change.

Key-words: Corticosterone; ACTH; Dexamethasone; Adrenal gland; PCBs; Reproduction 


\section{Introduction}

Species breeding in extreme environments, such as Polar Regions, are often subjected to a wide range of stressors (e.g., harsh weather, unpredictable food shortage, presence of predators) and an efficient response to these various stressors is vital to ensure self or brood survival (Wingfield et al., 2011; Wingfield, 2013). At the endocrine level, an environmental perturbation will stimulate the hypothalamic-pituitary-adrenal (HPA) axis: specifically corticotropinreleasing hormone $(\mathrm{CRH})$ will be released from the hypothalamus and will then stimulate the secretion of adrenocorticotropic hormone $(\mathrm{ACTH})$ from the anterior pituitary, which in turn will activate the synthesis of glucocorticoid hormones (corticosterone in birds, CORT henceforth) from the adrenal cortex (Wingfield, 2013). Concurrently, glucocorticoids will provide negative feedback signals for ACTH and CRH release (Wingfield, 2013). This hormonal cascade will trigger an array of physiological and behavioral adjustments that shift energy investment away from reproduction and redirect it towards survival (Wingfield and Sapolsky, 2003). In birds, CORT has therefore a strong connection with fitness traits such as breeding success, individual quality and survival (Angelier et al., 2009a, 2010; Bonier et al., 2009; Bókony et al., 2009; Breuner et al., 2008; Goutte et al., 2010a, 2011b; Lendvai et al., 2007; Kitaysky et al., 1999; Schultner et al., 2014).

Polar seabirds are top predators which often bear elevated levels of various environmental contaminants (e.g., Gabrielsen, 2007; Verreault et al., 2010). Contaminants are well present in aquatic biota (Gabrielsen and Sydnes, 2009) and diet is the principal route of contamination: persistent organic pollutant (POPs) which includes polychlorinated biphenyls (PCBs) and organochlorine pesticides (OCPs) and some heavy metals such as mercury ( $\mathrm{Hg})$ can bio-accumulate into individuals and bio-magnify along the food web (e.g., Dietz et al., 2000). Several of these environmental contaminants are endocrine disruptors (Ottinger et al., 2013; Tyler et al., 1998). Indeed those substances are able to mimic, antagonize, alter or modify 
endogenous hormone functions (e.g., Amaral Mendes, 2002). In free-living bird species, several studies have found significant relationships between contaminants and reproductive hormones such as steroids (Colborn et al., 1993; Giesy et al., 2003; Vos et al., 2000) and more recently with hormones from the HPA axis (Nordstad et al., 2012; Tartu et al., 2014, 2015a; Verboven et al., 2010). Specifically, in black-legged kittiwakes Rissa tridactyla, baseline and stressinduced CORT levels were positively associated with $\sum$ PCB concentrations (Nordstad et al., 2012; Tartu et al., 2014, 2015b). Also, in the most PCB-exposed Arctic seabird species, the glaucous gull Larus hyperboreus, a higher POP burden (including 58 PCB congeners, organochlorine pesticides, brominated flame retardants and their metabolically-derived products) was associated with higher baseline CORT levels in both sexes (Verboven et al., 2010). Moreover, in incubating snow petrels Pagodroma nivea, stress-induced CORT levels increased with increasing $\sum$ POPs (including 7 PCBs congeners and organochlorine pesticides, Tartu et al., 2015a). However the mechanisms through which contaminants may influence CORT regulation are poorly known, it is likely that such compounds may disrupt one of the many steps of CORT regulation causing dysfunction of the HPA axis. For instance, energy costs related to detoxification of POPs (Parkinson and Ogilvie, 2008; Preston and Hoffman, 2008) might stimulate CORT secretion. Additionally, the adrenal gland is suspected to be vulnerable to hazardous effects of POPs due to its high lipid content and multiple sites for interference (Hinson and Raven, 2006; Odermatt and Gumy, 2008).

When it comes to other environmental contaminants such as $\mathrm{Hg}$, studies of seabirds' eggs from the Canadian Arctic show an increasing trend of Hg levels from 1975 to 2005 in several species (Braune, 2007; Mallory and Braune, 2012). Hg is a well-known endocrine disruptor (reviewed in Tan et al., 2009) and some studies on free-ranging birds have reported inconclusive patterns between CORT and Hg concentrations (Franceschini et al., 2009; Herring et al., 2012; Tartu et al., 2015a; Wada et al., 2009; Wayland et al., 2002). Specifically, in 
common eiders Somateria mollissima borealis, stress-induced CORT levels were not related to liver Hg concentrations (Wayland et al., 2002), in adult tree swallows Tachycineta bicolor, baseline CORT concentrations were negatively related to blood $\mathrm{Hg}$ concentrations (Franceschini et al., 2009) and in chicks sampled in a $\mathrm{Hg}$ contaminated area, stress-induced CORT levels were lowered compared to less contaminated chicks (Wada et al., 2009). In Forster's tern chicks Sterna forsteri fecal CORT metabolites decreased with increasing blood Hg concentrations (Herring et al., 2012) and in snow petrels, baseline and stress-induced CORT concentrations were not related to blood $\mathrm{Hg}$ concentrations (Tartu et al., 2015a). Therefore, it is difficult to draw a general picture of contaminants-CORT relationships.

The aim of this study was to investigate the relationships between $\mathrm{Hg}$, PCBs and OCPs and some aspects of the HPA axis of an Arctic seabird, the black-legged kittiwake (hereafter 'kittiwake'). Svalbard kittiwakes bear significant amounts of blood $\mathrm{Hg}$, PCBs and OCPs (Nordstad et al., 2012; Savinova et al., 1995; Tartu et al., 2013, 2014), and three recent studies performed in the same breeding population where the present study was conducted have reported positive relationships between baseline and/or stress-induced CORT concentrations and blood PCB concentrations (Nordstad et al., 2012; Tartu et al., 2014, 2015b). However, it is still unknown whether these positive relationships are due to an increased adrenocortical responsiveness, a decreased negative feedback during acute stress, or both.

We specifically tested whether different aspects of the HPA axis of incubating male kittiwakes were related to blood $\mathrm{Hg}$, PCBs and OCPs concentrations. Males only were chosen since they are more contaminated than females (Nordstad et al., 2012; Tartu et al., 2013), thus hypothetically more susceptible to the hazardous effects of contaminants. To test these relationships, we measured the CORT response to a capture-restraint stress protocol (Wingfield, 1994) and birds were then injected with exogenous dexamethasone (DEX, a potent CORT receptor agonist, Astheimer et al., 1994) to test the efficiency of the negative feedback. The 
purpose of the DEX injection was also to induce inhibitory feedback of the HPA axis, thereby reducing confounding effects of endogenous ACTH release. Whereupon birds were injected with exogenous ACTH, a protocol used in several bird species to test the adrenal responsiveness (Angelier et al., 2009b; Dickens et al., 2009; Rich and Romero, 2005; Schmidt et al., 2012). If the exacerbated CORT release is connected to a higher adrenal activity in the most contaminated kittiwakes (Tartu et al., 2014, 2015b), we should observe a positive relationship between blood contaminant concentrations and plasma ACTH-induced CORT concentrations. Furthermore, contaminants may represent stressors (Bustnes et al., 2006); we therefore investigated the relationships between contaminant exposure and reproductive outputs such as hatching date and hatching success. We predicted that if $\mathrm{Hg}$, PCBs or OCPs stimulate CORT secretion, and since reproductive phenology and success are influenced by CORT levels in kittiwakes (Goutte et al., 2011a), then clutch size, hatching date and hatching success would be negatively associated with blood contaminants.

\section{Material and method}

\subsection{Ethic statement and study area}

The sampling of birds was approved by the Governor of Svalbard and by the Norwegian Animal Research Authority (NARA, permit number 4214). The study was conducted at Kongsfjorden, Svalbard $\left(78^{\circ} 54^{\prime}\right.$ N, $\left.12^{\circ} 13^{\prime} \mathrm{E}\right)$ from June 19th to July 4th 2012 during the incubating period of kittiwakes.

\subsection{CORT stress series: DEX and ACTH injections}

Thirty-four male kittiwakes were caught on their nests with a noose at the end of a $5 \mathrm{~m}$ fishing rod. A first blood sample (ca. $0.2 \mathrm{ml}$ ) was collected immediately after capture, from the alar vein with a $1 \mathrm{ml}$ heparinised syringe and a 25 -gauge needle to assess baseline CORT 
concentrations $\left(\mathrm{CORT}_{\mathrm{BL}}\right.$ henceforth). Bleeding time (i.e., time elapsed from capture to the end of the first blood sample: $2 \min 24 \mathrm{~s} \pm 28 \mathrm{~s}$ (SD) on average) was not related to $\mathrm{CORT}_{\mathrm{BL}}$ concentrations $\left(\mathrm{GLM}, \mathrm{F}_{1,32}=0.7, \mathrm{P}=0.395\right)$. Birds were then placed into a cloth bag and a second blood sample (ca. $0.2 \mathrm{ml}$ ) was collected from the alar vein $30 \mathrm{~min}$ later (30 min $13 \mathrm{~s} \pm$ $1 \min 22 \mathrm{~s}$ ) to assess stress-induced CORT concentrations (CORT $30 \mathrm{~min})$. Immediately following this blood sample, (30 min $58 \mathrm{~s} \pm 1 \min 26 \mathrm{~s}$ ), 30 birds were injected with DEX then put back into the cloth bag. Fifteen minutes later, we collected a third blood sample (CORT $45 \mathrm{~min}$, at 46 $\min 43 \mathrm{~s} \pm 2 \min 03 \mathrm{~s}$ ) and then immediately injected ACTH (47 $\min 29 \mathrm{~s} \pm 2 \min 05 \mathrm{~s})$, after which the birds were placed back into the bag again. Fifteen minutes following the ACTH injection (at $63 \min 08 \mathrm{~s} \pm 2 \min 33 \mathrm{~s}$ ), we collected a fourth and final blood sample $\left(\mathrm{CORT}_{60 \mathrm{~min}}\right)$. The volume of the final blood sample was $1.5 \mathrm{ml}$, and this sample was used to measure the concentration of contaminants (see below). All injections were given intramuscularly in the pectoral muscle. Concentrations were adapted to a body mass of $400 \mathrm{~g}$, which was the average body mass of incubating male kittiwakes in 2011 . We therefore injected $0.2 \mathrm{ml}$ of DEX (Dexazone $2 \mathrm{mg} / \mathrm{ml}$ Virbac, France) and $0.1 \mathrm{ml}$ porcine ACTH (Sigma Aldrich, 100 IU A6303 dissolved in $0.5 \mathrm{ml}$ Ringer's physiological solution), to obtain doses of $1 \mathrm{mg} / \mathrm{kg}$ dexamethasone (DEX) and $50 \mathrm{IU} / \mathrm{kg}$ ACTH which are considered as sufficient to elicit maximal CORT decrease and increase, respectively in other bird species (Dickens et al., 2009; Rich and Romero, 2005; Schmidt et al., 2012).

The stress series were shortened compared to those used in laboratory studies: blood samples were collected $15 \mathrm{~min}$ after each injection versus 45 min normally used in song sparrows to elicit maximal CORT responses induced by DEX and ACTH (Schmidt et al., 2012). We shortened the stress series to avoid leaving the nests unattended for a long period (which may increase the risk of the eggs being predated) sampled males were kept for 60 min (in total, from baseline sampling to post ACTH injection sample) versus $120 \mathrm{~min}$ in total in other studies 
(e.g., Schmidt et al., 2012). Four birds were used as control and injected Ringer's physiological solution to validate the effects of DEX and ACTH injections. We then calculated CORT induced changes following capture/handling protocol, DEX and ACTH injections. Stressinduced CORT: $\mathrm{CORT}_{\mathrm{SI}}=\mathrm{CORT}_{30 \mathrm{~min}}-\mathrm{CORT}_{\mathrm{BL}} ; \mathrm{CORT}_{\mathrm{DEX}}=\mathrm{CORT}_{45 \min }-\mathrm{CORT}_{30 \mathrm{~min}}$ and $\mathrm{CORT}_{\mathrm{ACTH}}=\mathrm{CORT}_{60 \mathrm{~min}}-\mathrm{CORT}_{45 \mathrm{~min}}$. Since absolute $\mathrm{CORT}$ concentrations may vary with age as in other seabird species (e.g., Goutte et al., 2010b), we decided to consider relative differences although using absolute or relative CORT values is currently open to debate (Romero, 2004).

\subsection{Clutch size, hatching dates and hatching success}

Kittiwakes were individually marked with metal rings and PVC plastic bands engraved with a three-letter code and fixed to the bird's tarsus for identification from a distance. Birds were weighed to the nearest $2 \mathrm{~g}$ using a Pesola spring balance, and their skull length (head + bill) was measured to the nearest $0.5 \mathrm{~mm}$ with a sliding calliper. For each bird we calculated a scaled mass index as a measure of body condition $\left(\mathrm{M}_{\mathrm{i}}\left[\mathrm{L}_{0} / \mathrm{L}_{\mathrm{i}}\right]^{\mathrm{b}} \mathrm{SMA}\right)$, where $\mathrm{M}_{\mathrm{i}}$ and $\mathrm{L}_{\mathrm{i}}$ are the body mass and the skull length of individual $i$ respectively; $b_{S M A}$ is the scaling exponent estimated by the SMA regression of $M$ on $L ; L_{0}$ is the average skull length, Peig and Green, 2009).Kittiwakes were marked with spots of dye on the forehead to distinguish them from their partner during subsequent observation and then released. Using a mirror at the end of an $8 \mathrm{~m}$ fishing rod, we checked the whole plot (ca. 117 nests) every two days to monitor the clutch size, the exact hatching date for the first egg (thereafter called "hatching date') and the number of eggs that hatched. The exact hatching date of the first egg laid was obtained for 25 individuals (21 birds injected with DEX and ACTH and 4 birds injected with Ringer's physiological solution). For 9 individuals the nest content was not visible for several checks as the parents would not stand when we approached the mirror. Consequently, we were not able to monitor 
the precise hatching date. Hatching date could be related to POPs for 19 treated birds (for 2 individuals blood volumes were too small) and to $\mathrm{Hg}$ for the 25 birds. We then considered the "'hatching success" binomially: $0=$ no eggs at all have hatched and $1=$ at least one egg has hatched.

\subsection{Molecular sexing and hormone assay}

For the 34 focal birds, blood samples were centrifuged, and plasma was decanted and stored at $-20{ }^{\circ} \mathrm{C}$ until assayed. After centrifugation, red cells were kept frozen for molecular sexing as well as for $\mathrm{Hg}$ analysis. The sex was determined by polymerase chain reaction amplification of part of two highly conserved genes (CHD) present on the sex chromosomes at UMR 7372 - CNRS Université de La Rochelle, as detailed in Weimerskirch et al. (2005). Plasma concentrations of CORT were determined by radioimmunoassay at UMR 7372 CNRS-Université de La Rochelle, as previously described (Lormée et al., 2003). The radioimmunoassay used to assay CORT has been validated for kittiwakes (Angelier et al., 2007; Chastel et al., 2005; Goutte et al., 2011a; Nordstad et al., 2012). All samples were run in one assay. To measure intra-assay variation, we included 4 different referents 10 times in the assay and kittiwake plasma samples from previous years. From this, the intra-assay variation was 6.7\%. Plasma CORT levels were measured in baseline, stress-, DEX- (or control) and ACTHinduced (or control) CORT samples (Fig. 1).

\subsection{POPs determination in plasma}

POPs were analyzed from whole blood of 27 birds injected with DEX and ACTH, for three individuals blood volumes were too small for POP measurements. Analyses were performed at the Norwegian Institute for Air Research (NILU) in Troms $\varnothing$ and the following compounds were searched for: the PCBs (CB-28, -52, -99, -101, -105, -118, -138, -153, -180, - 
183, -187 and -194), and the organochlorine pesticides (OCPs: o,p' DDT, $p, p$ ' DDT, $p, p$ ' DDE, $o, p$ ' DDE, $o, p^{\prime}$ DDD, $p, p$ ' DDD, $\alpha-, \beta-, \gamma-\mathrm{HCH}, \mathrm{HCB}$, trans-, cis-chlordane, oxychlordane, trans-, cis-nonachlor and mirex). To a blood sample of $0.5-1.5 \mathrm{ml}$, an internal standard solution was added $\left({ }^{13} \mathrm{C}\right.$-labeled compounds from Cambridge Isotope Laboratories: Woburn, MA, USA). The sample was extracted twice with $6 \mathrm{ml}$ of $\mathrm{n}$-hexane, after denaturation with ethanol and a saturated solution of ammonium sulfate in water. Matrix removal on florisil columns, separation on an Agilent Technology 7890 GC and detection on an Agilent Technology 5975C MSD were performed as described by Herzke et al. (2009). The limit for detection (LoD) was threefold the signal-to-noise ratio, and for the compounds investigated the limit ranged from 1.1 to $632.7 \mathrm{pg} / \mathrm{g}$ wet weights (ww). For validation of the results, blanks (clean and empty glass tubes treated like a sample, 3 in total) were run for every 10 samples, while standard reference material (3 in total, 1589a human serum from NIST) also was run for every 10 samples. The accuracy of the method was between $70 \%$ and $108 \%$. For further investigations, concentrations below LoD were assigned by LoD value, and only compounds detected in at least $70 \%$ of the individuals were included into the statistical analyses (Noël et al., 2009). In incubating male kittiwakes the following PCBs (CB-28, -99, -105, -118, -138, -153, -180, -183 and -187) and OCPs ( $p, p^{\prime}$-DDE, HCB, oxychlordane, trans-, cis-nonachlor and mirex) were detected in at least $70 \%$ of the individuals (means \pm SD and ranges are given in Table 1).

\subsection{Hg determination in red blood cells}

Total Hg was measured for 34 individuals at LIENSs (La Rochelle), as described by Bustamante et al. (2006) from freeze-dried and powdered red blood cells (hereafter called 'blood') in an Advanced $\mathrm{Hg}$ Analyzer spectrophotometer (Altec AMA 254). At least two aliquots ranging from 5 to $10 \mathrm{mg}$ were analyzed for each individual and quality assessment was measured by repeated analyses of certified reference material TORT-2 (lobster hepatopancreas, 
NRCC; certified value $0.27 \pm 0.06 \mu \mathrm{g} / \mathrm{g}$ with recoveries of $98-102 \%)$. Hg concentrations are expressed in $\mu \mathrm{g} / \mathrm{g}$ dry weight (dw).

\subsection{Statistics}

All statistical analyses were performed using R 2.13.1 (R Development Core Team 2008). To validate the effects of DEX and ACTH injections on CORT secretion, we used generalized linear mixed models (GLMM) with bird identity as a random effect (dependent variable: 'CORT'; independent factors 'Time' and 'Treatment'). Then we tested whether CORT would vary following handling stress and injections (controls, DEX, ACTH) and tested whether CORT responses following DEX and ACTH injections were related to body mass and to the hour of the day. In order to do so, we used generalized linear models (GLM) with a normal error distribution and an identity link function. We summed POPs as follows: $\sum$ PCBs ( $n=9$ congeners) and $\sum$ OCPs ( $n=6$ congeners). First, we tested whether absolute concentration of 'CORT $\mathrm{BL}_{\mathrm{L}}, \mathrm{CORT}_{30 \mathrm{~min}}, \mathrm{CORT}_{45 \mathrm{~min}}$ and $\mathrm{CORT}_{60 \mathrm{~min}}$ ' and contaminants ' $\sum \mathrm{PCBs}, \sum \mathrm{OCPs}$ and $\mathrm{Hg}$ ' were related to 'sampling date' and 'scaled mass index'. Second, we tested whether CORT responses to stress series 'CORT $\mathrm{BL}_{\mathrm{BL}}, \mathrm{CORT}_{\mathrm{SI}}, \mathrm{CORT}_{\mathrm{DEX}}$ and $\mathrm{CORT}_{\mathrm{ACTH}}$ ' were related to contaminants ' $\sum$ PCBs, $\sum$ OCPs and Hg' and. Finally, we tested if 'clutch size', 'hatching date' and 'hatching success' were related to 'scaled mass index' and contaminants ' $\sum$ PCBs, $\sum$ OCPs and Hg'. Clutch size and hatching success were tested using a GLM with a Poisson/binomial error distribution and a log/logit link function, respectively. Diagnostic plots were used to assess whether the data sufficiently met the assumptions of the model, $\sum$ PCBs and $\sum$ OCPs were log10 transformed. Values are mean \pm SD. 


\section{Results}

\subsection{CORT stress series}

CORT concentrations were significantly related to the time of blood sampling, the treatment and their interaction (GLMM, time: $\mathrm{F}_{3,96}=340.5, \mathrm{P}<0.001$; treatment: $\mathrm{F}_{1,32}=6.3, \mathrm{P}$ $=0.017$; time $\mathrm{x}$ treatment: $\left.\mathrm{F}_{3,96}=12.15, \mathrm{P}<0.001\right)$. Considering the significant relationship between the interaction of time $\mathrm{x}$ treatment on CORT: CORT $\mathrm{BL}$ and $\mathrm{CORT}_{30 \mathrm{~min}}$ were not different between "treated" and "control' birds (GLMM, CORT $\mathrm{BL}_{\mathrm{BL}} \mathrm{F}_{1,32}<0.1, \mathrm{P}=0.846$; $\mathrm{CORT}_{30 \mathrm{~min}}: \mathrm{F}_{1,32}=0.1, \mathrm{P}=0.743$ ) whereas $\mathrm{CORT}_{45 \min }$ and $\mathrm{CORT}_{60 \mathrm{~min}}$ were significantly lower in the "treated" birds compared to the "control" birds (GLMM, CORT $45 \min : \mathrm{F}_{1,32}=16.6, \mathrm{P}<$ 0.001; CORT $\left._{60 \mathrm{~min}}: \mathrm{F}_{1,32}=15.3, \mathrm{P}<0.001\right)$. In treated birds, CORT concentrations significantly increased following the capture-restraint protocol $\left(\mathrm{GLMM}, \mathrm{F}_{1,29}=449.3, \mathrm{P}<0.001\right)$ and CORT concentration significantly decreased over 15 min after the DEX injection (GLMM, $F_{1,29}=$ 160.0, $\mathrm{P}<0.001)$. Lastly, ACTH injection did not result in a significant increase of CORT within $\sim 15$ min of action (GLMM, $\left.\mathrm{F}_{1,29}=1.7, \mathrm{P}=0.208\right)$. However, we observed a large interindividual variation (Fig. 1A): for some individuals CORT concentration did not increase or even decreased following ACTH injection, yet in some kittiwakes CORT increased as depicted by positive CORT values on Fig. 2B. Incubating male kittiwakes were heavier than the average body mass used for DEX and ACTH concentrations (427.2 $\pm 31 \mathrm{~g}$, range: 360-490), however, CORT responses were not related to body mass or to its interaction with time (GLMM, body mass: $F_{1,32}=0.18, P=0.673$; time $x$ body mass: $\left.F_{3,96}=0.76, P=0.519\right)$. In control birds, CORT significantly increased following the capture-restraint protocol $\left(\mathrm{GLMM}, \mathrm{F}_{1,3}=78.5, \mathrm{P}=0.003\right)$ then remained steady $\left(\mathrm{GLMM}\right.$, from $\mathrm{CORT}_{30 \min }$ to $\mathrm{CORT}_{45 \min } \mathrm{F}_{1,3}=2.4, \mathrm{P}=0.220$, from $\mathrm{CORT}_{45 \min }$ to $\mathrm{CORT}_{60 \mathrm{~min}}, \mathrm{~F}_{1,3}<0.1, \mathrm{P}=0.983$ Fig. $\left.1 \mathrm{~B}\right)$. The hour of the day was not related to $\operatorname{CORT}_{\mathrm{DEX}}$ and $\mathrm{CORT}_{\mathrm{ACTH}}\left(\mathrm{GLM}, \mathrm{F}_{1,28}=0.4, \mathrm{P}=0.526\right.$ and $\mathrm{F}_{1,28}<0.1, \mathrm{P}=0.986$, respectively). 


\subsection{Contaminants and CORT in relation to sampling date and scaled mass index}

Absolute concentrations of $\mathrm{CORT}_{\mathrm{BL}}, \mathrm{CORT}_{30 \mathrm{~min}}, \mathrm{CORT}_{45 \mathrm{~min}}$ and $\mathrm{CORT}_{60 \mathrm{~min}}$ were not related to sampling date nor to scaled mass index which was used as a measure of body condition (GLM, $\mathrm{F}_{1,28}<1.3, \mathrm{P}>0.269$ for all tests). $\mathrm{Hg}, \sum \mathrm{PCBs}$ or $\sum \mathrm{OCPs}$ were not related to sampling date (GLM, Hg: $\mathrm{F}_{1,32}=0.6, \mathrm{P}=0.428 ; \sum \mathrm{PCBs}: \mathrm{F}_{1,25}=0.1, \mathrm{P}=0.745$ and $\sum \mathrm{OCPs}$ : GLM, $\left.F_{1,25}=0.2, P=0.674\right) . H g$ concentrations were not related to scaled mass index (GLM, $\left.\mathrm{F}_{1,32}=0.1, \mathrm{P}=0.757\right)$, however $\sum \mathrm{PCBs}$ and $\sum \mathrm{OCPs}$ increased with decreasing scaled mass index (GLM, $\sum$ PCBs: $\mathrm{F}_{1,25}=4.3, \mathrm{P}=0.048$ and $\left.\sum \mathrm{OCPs} \mathrm{F}_{1,25}=4.9, \mathrm{P}=0.037\right)$.

\subsection{Relationships between the HPA activity and contaminants}

$\mathrm{CORT}_{\mathrm{BL}}, \mathrm{CORT}_{\mathrm{SI}}$ and $\mathrm{CORT}_{\mathrm{DEX}}($ Fig. 2A) were not related to contaminants $(\mathrm{Hg}$,

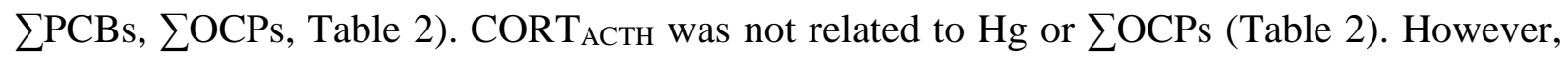
$\mathrm{CORT}_{\mathrm{ACTH}}$ was positively associated with $\sum$ PCBs (Fig. 2B, Table 2).

3.4. Clutch size, hatching dates and hatching success in relation to scaled mass index and contaminants

Clutch size (1, 2 or 3 eggs were laid) was not related to scaled mass index (GLM, $\chi^{2}<$ $0.1, \mathrm{P}=0.886)$ or contaminants (GLM, $\sum \mathrm{PCBs}: \chi^{2}=0.1, \mathrm{P}=0.721 ; \sum \mathrm{OCPs}: \chi^{2}<0.1, \mathrm{P}=0.977$ and $\left.\mathrm{Hg}: \chi^{2}=0.4, \mathrm{P}=0.529\right)$. Hatching date was not related to scaled mass index (GLM, $\mathrm{F}_{1,23}=$ $0.2, \mathrm{P}=0.663)$ but was positively related to $\sum \mathrm{PCBs}\left(\mathrm{GLM}, \mathrm{F}_{1,17}=16.3, \mathrm{P}<0.001\right.$; Fig. 3$)$ and $\sum$ OCPs $\left(\mathrm{GLM}, \mathrm{F}_{1,17}=9.2, \mathrm{P}=0.008\right)$. The relationship between hatching date and $\mathrm{Hg}$ was only close to statistical significance $\left(\mathrm{GLM}, \mathrm{F}_{1,23}=3.4, \mathrm{P}=0.076\right)$. With regard to hatching success, individuals with no chicks that hatched tended to have a lower scaled mass index (GLM, $\chi^{2}=$ 3.7, $\mathrm{P}=0.055)$. Hatching success was not related to contaminants $\left(\mathrm{GLM}, \sum \mathrm{PCBs}: \chi^{2}=0.2, \mathrm{P}=\right.$ 0.635; $\sum$ OCPs: $\chi^{2}<0.1, \mathrm{P}=0.820$ and $\left.\mathrm{Hg}: \chi^{2}<0.1, \mathrm{P}=0.904\right)$. 


\section{Discussion}

\subsection{HPA activity and contaminants}

The aim of this study was to test whether the positive association between CORT secretion and PCB contamination, which has been repeatedly observed in this Svalbard population of kittiwakes (Nordstad et al., 2012; Tartu et al., 2014, 2015b), resulted from an inefficient negative feedback mechanism or from a higher adrenal activity. We also investigated if other contaminants (Hg or OCPs) would be related to some aspect of the HPA axis activity. Contrary to what has been reported in previous studies on kittiwakes from the same breeding colony, we did not find any relationship between contaminants, CORT $_{\mathrm{BL}}$ and $\mathrm{CORT}_{\mathrm{SI}}$ (Nordstad et al., 2012; Tartu et al., 2014, 2015b). CORT $\mathrm{DEX}$ was not related to contaminants, suggesting that environmental contaminants may not alter the functioning of glucocorticoid receptors on the hypothalamus or the pituitary. According to our prediction, the adrenal responsiveness $\left(\mathrm{CORT}_{\mathrm{ACTH}}\right)$ was positively associated to $\sum \mathrm{PCBs}$ in male kittiwakes. Administration of a standardized dose of ACTH is an alternative approach to measure the stress response that is specifically due to variation in the sensitivity of the adrenal cortex to ACTH. Response to exogenous ACTH may also provide a more accurate measure of glucocorticoid production than response to restraint stress (Wada et al., 2007; Schmidt et al., 2012). However, in some birds ACTH injection was not effective and CORT levels even decreased in birds with lower levels of PCBs. These results are surprising but could be the consequence of a too short time of action of ACTH or maybe the dose of ACTH we used was too low to elicit a maximal CORT release. The time necessary to elicit a maximal CORT release post-ACTH injection in song sparrows was 45 min (e.g., Schmidt et al., 2012) and our experimental kittiwakes were only exposed for $15 \mathrm{~min}$. Also we were not able to previously validate if the ACTH dose we used would elicit a maximal CORT release in kittiwakes. Further studies would be needed to 
test the dose-response between ACTH injection and CORT secretion in kittiwakes. However, relative CORT differences in response to $\mathrm{ACTH}$ injection $\left(\mathrm{CORT}_{\mathrm{ACTH}}\right)$ were significantly related to blood PCB concentrations in incubating male kittiwakes. Consequently, this result suggests that the adrenal activity of male kittiwakes bearing high levels of PCBs is exacerbated. An exacerbated adrenal activity may result from increased number of ACTH-receptors (ACTHR) on the adrenals. In mammals, ACTH is one of the few polypeptide hormones having a positive trophic effect on its own receptors (Penhoat et al., 1989; Beuschlein et al., 2001). Although there is no evidence for such a relationship in birds, we may assume that a similar effect to what is observed in mammals would occur in birds. Thus, the positive association between adrenal activity and PCB contamination in kittiwakes may be related to an excess of ACTH input to adrenals. In experimental studies, causal effects of POPs on ACTH-R have already been described: PCB126 can increase ACTH-R levels in human adrenocortical cells (Li and Wang, 2005), and a pesticide, the methyl thiophanate, could mimic ACTH and directly activate ACTH-R on the adrenal glands of lizards Podarcis sicula (De Falco et al., 2007). The present study and other recent findings on male and female kittiwakes (Nordstad et al., 2012; Tartu et al., 2014, 2015b) show that PCBs and not OCPs are associated with CORT secretion in this species and that $\mathrm{Hg}$ does not seem related to the adrenocortical response or to the adrenal activity in kittiwakes. Relationships between CORT and PCBs could also be environmentdependent. Indeed, in the present study, $\mathrm{CORT}_{\mathrm{BL}}$ or $\mathrm{CORT}_{\mathrm{SI}}$ were not related to PCBs contrary to results found in kittiwakes from the same breeding colony (Nordstad et al., 2012; Tartu et al., 2014, 2015b). The nature of the relationship between CORT and PCBs could depend of the level of contamination (Tartu et al., 2015b). In 2011, when significant relationships were found between CORT (baseline and stress-induced levels) and $\sum$ PCBs, the levels of some CB congeners differed: CB-28 and CB-194 were detected in less and more than $70 \%$ of the individuals, respectively. Seven individuals were caught in 2012 (the present study) and in 2011 
and when considering indicator PCBs (i.e., $\sum$ CB-28, -52, -101, -118, -138, -153 and -180) which are highly bioaccumulative in a wide range of polar seabird species (Gabrielsen et al., 1995; Savinova et al., 1995), the levels were significantly lower in 2012 than in 2011 (GLMM, $\left.\mathrm{F}_{1,6}=14.21, \mathrm{P}=0.009\right)$. If we consider that CORT-PCB relationships could depend of the level of contamination, and follow an inverted U-shaped pattern as depicted by Tartu et al., 2015b, we may suppose that at lower concentrations PCBs may stimulate CORT secretion whereas at higher concentrations the relationship between CORT and PCBs could reach a plateau and therefore not be observable. In the present study, $\sum$ POPs significantly increased with decreasing body-condition as depicted by scaled mass index. Since POPs are stored into fatty tissues it is not surprising that male kittiwakes with poor body reserves show higher concentrations of PCBs and OCPs in their plasma. Such relationships have been observed in several bird species, such as kittiwakes (Henriksen et al., 1996; Tartu et al., 2014), glaucous gulls L. hyperboreus (Sagerup et al., 2009), common eiders Somateria mollissima (Bustnes et al., 2010, 2012), sparrowhawks Accipiter nisus (Bogan and Newton, 1977) and white-tailed eagle Haliaeetus albicilla (Kenntner et al., 2003). Body-condition in birds predicts a wide range of fitness related traits, such as incubation pattern, breeding success or survival (see Labocha and Hayes, 2012 for a review). And because lower body-condition is positively associated with blood POP concentrations, POPs could therefore become more available for more sensitive vital organs such as brain, kidneys and liver (Henriksen et al., 1996; Fuglei et al., 2007).

\subsection{Fitness in relation to contaminants}

In our study, we observed a positive relationship between $\sum$ PCBs, $\sum$ OCPs and hatching date. The first egg of the most contaminated male kittiwakes hatched later in the season. The same pattern has been found in female south polar skuas Catharacta maccormicki (Bustnes et al., 2007). A delayed hatching date could be the consequence of an impaired incubation 
behavior. Previous studies on captive American kestrels Falco sparverius and free-ranging glaucous gulls have reported altered incubation behaviors in relation to increasing PCB burden (Bustnes et al., 2001; Fisher et al., 2006; Verboven et al., 2009). Although behavior and egglaying date were not measured in incubating male kittiwakes, we could assume that high PCBs and OCPs burden may alter incubation behavior leading in a delayed hatching date. Further studies would be needed to support this assumption. Contrary to our prediction, blood contaminants were not negatively associated with hatching success. However, in case of poor foraging conditions when CORT secretion is stimulated (Kitaysky et al., 1999; Goutte et al., 2014), it is possible that male kittiwakes bearing high levels of PCBs would be more sensitive to environmental stress and would be less able to properly incubate their eggs than less polluted individuals. More generally, an exacerbated adrenal responsiveness to stress, as depicted by the CORT response to $\mathrm{ACTH}$, often mirrors poor fitness related traits such as poor parental investment (Angelier et al., 2009a,b; Bókony et al., 2009; Goutte et al., 2011b; Lendvai et al., 2007) or lower adult survival (Blas et al., 2007; Goutte et al., 2010a; Romero, 2012). Thus, although most legacy POPs show decreasing trend in Arctic seabirds (e.g., Helgason et al., 2011), the prevalence of PCBs could make individuals more susceptible to other environmental stressors such as ongoing climate change (Jenssen, 2005).

Acknowledgments: This project was supported by Institut Polaire Français (IPEV project 330 to O. Chastel), Agence National de la Recherche (ANR project PolarTop to O. Chastel), the Norwegian Research Council and the FRAM Centre (COPOL to G.W. Gabrielsen \& J.O. Bustnes) and Svalbard Science Forum (Arctic Field Grant 1786 to S. Tartu). The authors are grateful to the Plateforme Analyses Elémentaires for the access to their analytical facilities. The authors thank C. Parenteau, C. Trouvé, S. Dano, for their excellent technical assistance in hormones assays and molecular sexing, the NILU staff for their assistance during the chemical 
analyses, C. Churlaud and M. Brault-Favrou for their help in $\mathrm{Hg}$ determination, and two anonymous referees for their very useful comments on a previous version of the manuscript. 


\section{References}

Amaral Mendes, J.J., 2002. The endocrine disrupters: a major medical challenge. Food Chem. Toxicol. 40, 781-788.

Angelier, F., Clément-Chastel, C., Gabrielsen, G.W., Chastel, O., 2007. Corticosterone and time-activity budget: an experiment with black-legged kittiwakes. Horm. Behav. 52, 482-491.

Angelier, F., Clément-Chastel, C., Welcker, J., Gabrielsen, G.W., Chastel, O., 2009a. How does corticosterone affect parental behaviour and reproductive success? A study of prolactin in black-legged kittiwakes. Functional Ecology 23, 784-793. doi:10.1111/j.13652435.2009.01545.x

Angelier, F., Moe, B., Blanc, S., Chastel, O., 2009b. What Factors Drive Prolactin and Corticosterone Responses to Stress in a Long-Lived Bird Species (Snow Petrel Pagodroma nivea)? Physiological and Biochemical Zoology 82, 590-602. doi:10.1086/592846

Angelier, F., Wingfield, J.C., Weimerskirch, H., Chastel, O., 2010. Hormonal correlates of individual quality in a long-lived bird: a test of the "corticosterone-fitness hypothesis". Biol. Lett. 6, 846-849. doi:10.1098/rsbl.2010.0376

Astheimer, L.B., Buttemer, W.A., Wingfield, J.C., 1994. Gender and Seasonal Differences in the Adrenocortical Response to ACTH Challenge in an Arctic Passerine, Zonotrichia leucophrys gambelii. General and Comparative Endocrinology 94, 33-43. doi:10.1006/gcen.1994.1057

Beuschlein, F., Fassnacht, M., Klink, A., Allolio, B., Reincke, M., 2001. ACTH-receptor expression, regulation and role in adrenocortial tumor formation. Eur J Endocrinol 144, 199-206. doi:10.1530/eje.0.1440199

Blas, J., Bortolotti, G.R., Tella, J.L., Baos, R., Marchant, T.A., 2007. Stress response during development predicts fitness in a wild, long lived vertebrate. PNAS 104, 8880-8884. doi:10.1073/pnas.0700232104

Bogan, J.A., Newton, I., 1977. Redistribution of DDE in sparrowhawks during starvation. Bull. Environ. Contam. Toxicol. 18, 317-321. doi:10.1007/BF01683425

Bókony, V., Lendvai, Á.Z., Liker, A., Angelier, F., Wingfield, J.C., Chastel, O., 2009. Stress Response and the Value of Reproduction: Are Birds Prudent Parents? The American Naturalist 173, 589-598. doi:10.1086/597610

Bonier, F., Martin, P.R., Moore, I.T., Wingfield, J.C., 2009. Do baseline glucocorticoids predict fitness? Trends in Ecology \& Evolution 24, 634-642. doi:10.1016/j.tree.2009.04.013

Braune, B.M., 2007. Temporal trends of organochlorines and mercury in seabird eggs from the Canadian Arctic, 1975-2003. Environmental Pollution 148, 599-613. doi:10.1016/j.envpol.2006.11.024

Breuner, C.W., Patterson, S.H., Hahn, T.P., 2008. In search of relationships between the acute adrenocortical response and fitness. General and Comparative Endocrinology 157, 288295. doi:10.1016/j.ygcen.2008.05.017

Bustamante, P., Lahaye, V., Durnez, C., Churlaud, C., Caurant, F., 2006. Total and organic Hg concentrations in cephalopods from the North Eastern Atlantic waters: Influence of geographical origin and feeding ecology. Science of The Total Environment 368, 585596. doi:10.1016/j.scitotenv.2006.01.038

Bustnes, J. O., Bakken, V., Erikstad, K. E., Mehlum, F., Skaare, J. U., 2001. Patterns of incubation and nest-site attentiveness in relation to organochlorine (PCB) contamination in glaucous gulls. Journal of Applied Ecology 38, 791-801. doi:10.1046/j.13652664.2001.00633.x 
Bustnes, J.O., Erikstad, K.E., Hanssen, S.A., Tveraa, T., Folstad, I., Skaare, J.U., 2006. Antiparasite treatment removes negative effects of environmental pollutants on reproduction in an Arctic seabird. Proc. R. Soc. B 273, 3117-3122. doi:10.1098/rspb.2006.3687

Bustnes, J.O., Tveraa, T., Varpe, Ø., Henden, J.A., Skaare, J.U., 2007. Reproductive performance and organochlorine pollutants in an Antarctic marine top predator: The south polar skua. Environment International 33, 911-918. doi:10.1016/j.envint.2007.04.010

Bustnes, J.O., Moe, B., Herzke, D., Hanssen, S.A., Nordstad, T., Sagerup, K., Gabrielsen, G.W., Borgå, K., 2010. Strongly increasing blood concentrations of lipid-soluble organochlorines in high arctic common eiders during incubation fast. Chemosphere 79, 320-325. doi:10.1016/j.chemosphere.2010.01.026

Bustnes, J.O., Moe, B., Hanssen, S.A., Herzke, D., Fenstad, A.A., Nordstad, T., Borgå, K., Gabrielsen, G.W., 2012. Temporal Dynamics of Circulating Persistent Organic Pollutants in a Fasting Seabird under Different Environmental Conditions. Environ. Sci. Technol. 46, 10287-10294. doi:10.1021/es301746j

Chastel, O., Lacroix, A., Weimerskirch, H., Gabrielsen, G.W., 2005. Modulation of prolactin but not corticosterone responses to stress in relation to parental effort in a long-lived bird. Horm. Behav. 47, 459-466.

Colborn, T., vom Saal, F.S., Soto, A.M., 1993. Developmental effects of endocrine disrupting chemicals in wildlife and humans. Environ. Health Perspect. 101, 378-384.

De Falco, M., Sciarrillo, R., Capaldo, A., Russo, T., Gay, F., Valiante, S., Varano, L., Laforgia, V., 2007. The Effects of the Fungicide Methyl Thiophanate on Adrenal Gland Morphophysiology of the Lizard, Podarcis sicula. Arch Environ Contam Toxicol 53, 241-248. doi:10.1007/s00244-006-0204-2

Dickens, M.J., Earle, K.A., Romero, L.M., 2009. Initial transference of wild birds to captivity alters stress physiology. General and Comparative Endocrinology 160, 76-83. doi:10.1016/j.ygcen.2008.10.023

Dietz, R., Riget, F., Cleemann, M., Aarkrog, A., Johansen, P., Hansen, J.C., 2000. Comparison of contaminants from different trophic levels and ecosystems. Sci. Total Environ. 245, 221-231.

Fisher, S.A., Bortolotti, G.R., Fernie, K.J., Bird, D.M., Smits, J.E., 2006. Behavioral variation and its consequences during incubation for American kestrels exposed to polychlorinated biphenyls. Ecotoxicology and Environmental Safety 63, 226-235. doi:10.1016/j.ecoenv.2005.07.021

Franceschini, M.D., Lane, O.P., Evers, D.C., Reed, J.M., Hoskins, B., Romero, L.M., 2009. The corticosterone stress response and mercury contamination in free-living tree swallows, Tachycineta bicolor. Ecotoxicology 18, 514-521. doi:10.1007/s10646-0090309-2

Fuglei, E., Bustnes, J.O., Hop, H., Mørk, T., Björnfoth, H., van Bavel, B., 2007. Environmental contaminants in arctic foxes (Alopex lagopus) in Svalbard: Relationships with feeding ecology and body condition. Environmental Pollution 146, 128-138. doi:10.1016/j.envpol.2006.06.036

Gabrielsen, G.W., 2007. Levels and effects of persistent organic pollutants in arctic animals. In: Ørbæk, D.J.B., Kallenborn, D.R., Tombre, D.I., Hegseth, D.E.N., Falk-Petersen, D.S., Hoel, D.A.H. (Eds.), Arctic Alpine Ecosystems and People in a Changing Environment. Springer, Berlin Heidelberg, pp. 377-412.

Gabrielsen, G.W., Sydnes, L., 2009. Pollution in the Barents sea. In: Ecosystem Barents Sea. Tapir Academic Press. 
Gabrielsen, G.W., Skaare, J.U., Polder, A., Bakken, V., 1995. Chlorinated hydrocarbons in glaucous gulls (Larus hyperboreus) in the southern part of Svalbard. Sci. Total Environ. 160-161, 337-346. http://dx.doi.org/10.1016/0048-9697(95)04367-A.

Giesy, J.P., Feyk, L.A., Jones, P.D., Kannan, K., Sanderson, T., 2003. Review of the effects of endocrine-disrupting chemicals in birds. Pure Appl. Chem. 75, 2287-2303.

Goutte, A., Angelier, F., Welcker, J., Moe, B., Clément-Chastel, C., Gabrielsen, G.W., Bech, C., Chastel, O., 2010. Long-term survival effect of corticosterone manipulation in Black-legged kittiwakes. General and Comparative Endocrinology 167, 246-251. doi:10.1016/j.ygcen.2010.03.018

Goutte, A., Clément-Chastel, C., Moe, B., Bech, C., Gabrielsen, G.W., Chastel, O., 2011a. Experimentally reduced corticosterone release promotes early breeding in black-legged kittiwakes. J Exp Biol 214, 2005-2013. doi:10.1242/jeb.051979

Goutte, A., Antoine, É., Chastel, O., 2011b. Experimentally delayed hatching triggers a magnified stress response in a long-lived bird. Hormones and Behavior 59, 167-173. doi:10.1016/j.yhbeh.2010.11.004

Goutte, A., Angelier, F., Bech, C., Clément-Chastel, C., Dell'Omo, G., Gabrielsen, G.W., Lendvai, Á.Z., Moe, B., Noreen, E., Pinaud, D., 2014. Annual variation in the timing of breeding, pre-breeding foraging areas and corticosterone levels in an Arctic population of black-legged kittiwakes. Mar Ecol Prog Ser 496, 233-247.

Helgason, L.B., Sagerup, K., Gabrielsen, G.W. 2011. Temporal trends and contaminant profiles of persistent organic pollutants (POPs) in seabird eggs from Northern Norway and Svalbard. Loganathan, B.G., Lam, P.K.S. (eds.). Global Contamination Trends of Persistent Organic Chemicals. CRC Press.

Henriksen, E.O., Gabrielsen, G.W., Skaare, J.U., 1996. Levels and congener pattern of polychlorinated biphenyls in kittiwakes (Rissa tridactyla), in relation to mobilization of body-lipids associated with reproduction. Environmental Pollution 92, 27-37. doi:10.1016/0269-7491(95)00087-9

Herring, G., Ackerman, J.T., Herzog, M.P., 2012. Mercury Exposure May Suppress Baseline Corticosterone Levels in Juvenile Birds. Environ. Sci. Technol. 46, 6339-6346. doi:10.1021/es300668c

Herzke, D., Nygård, T., Berger, U., Huber, S., Røv, N., 2009. Perfluorinated and other persistent halogenated organic compounds in European shag (Phalacrocorax aristotelis) and common eider (Somateria mollissima) from Norway: A suburban to remote pollutant gradient. Science of The Total Environment 408, 340-348. doi:10.1016/j.scitotenv.2009.08.048

Hinson, J.P., Raven, P.W., 2006. Effects of endocrine-disrupting chemicals on adrenal function. Best Practice \& Research Clinical Endocrinology \& Metabolism 20, 111-120. doi:10.1016/j.beem.2005.09.006

Jenssen, B.M., 2005. Endocrine-Disrupting Chemicals and Climate Change: A Worst-Case Combination for Arctic Marine Mammals and Seabirds? Environmental Health Perspectives 114, 76-80. doi:10.1289/ehp.8057

Kenntner, N., Krone, O., Oehme, G., Heidecke, D., Tataruch, F., 2003. Organochlorine contaminants in body tissue of free-ranging white-tailed eagles from northern regions of Germany. Environmental Toxicology and Chemistry 22, 1457-1464. doi:10.1002/etc.5620220706

Kitaysky, A.S., Wingfield, J.C., Piatt, J.F., 1999. Dynamics of food availability, body condition and physiological stress response in breeding Black-legged Kittiwakes. Functional Ecology 13, 577-584. doi:10.1046/j.1365-2435.1999.00352.x

Labocha, M.K., Hayes, J.P., 2012. Morphometric indices of body condition in birds: a review. J Ornithol 153, 1-22. doi:10.1007/s10336-011-0706-1 
Lendvai, Á.Z., Giraudeau, M., Chastel, O., 2007. Reproduction and modulation of the stress response: an experimental test in the house sparrow. Proc. R. Soc. B 274, 391-397. doi:10.1098/rspb.2006.3735

Li, L.A., Wang, P. W., 2005. PCB126 Induces Differential Changes in Androgen, Cortisol, and Aldosterone Biosynthesis in Human Adrenocortical H295R Cells. Toxicol. Sci. 85, 530-540. doi:10.1093/toxsci/kfi105

Lormée, H., Jouventin, P., Trouve, C., Chastel, O., 2003. Sex-specific patterns in baseline corticosterone and body condition changes in breeding Red-footed Boobies Sula sula. Ibis 145, 212-219. doi:10.1046/j.1474-919X.2003.00106.x

Mallory, M.L., Braune, B.M., 2012. Tracking contaminants in seabirds of Arctic Canada: Temporal and spatial insights. Marine Pollution Bulletin 64, 1475-1484. doi:10.1016/j.marpolbul.2012.05.012

Noël, M., Barrett-Lennard, L., Guinet, C., Dangerfield, N., Ross, P.S., 2009. Persistent organic pollutants (POPs) in killer whales (Orcinus orca) from the Crozet Archipelago, southern Indian Ocean. Marine Environmental Research 68, 196-202. doi:10.1016/j.marenvres.2009.06.009

Nordstad, T., Moe, B., Bustnes, J.O., Bech, C., Chastel, O., Goutte, A., Sagerup, K., Trouvé, C., Herzke, D., Gabrielsen, G.W., 2012. Relationships between POPs and baseline corticosterone levels in black-legged kittiwakes (Rissa tridactyla) across their breeding cycle. Environmental Pollution 164, 219-226. doi:10.1016/j.envpol.2012.01.044

Odermatt, A., Gumy, C., 2008. Glucocorticoid and mineralocorticoid action: Why should we consider influences by environmental chemicals? Biochemical Pharmacology 76, 11841193. doi:10.1016/j.bcp.2008.07.019

Ottinger, M.A., Carro, T., Bohannon, M., Baltos, L., Marcell, A.M., McKernan, M., Dean, K.M., Lavoie, E., Abdelnabi, M., 2013. Assessing effects of environmental chemicals on neuroendocrine systems: potential mechanisms and functional outcomes. Gen. Comp. Endocrinol. 190, 194-202.

Peig, J., Green, A.J., 2009. New perspectives for estimating body condition from mass/length data: the scaled mass index as an alternative method. Oikos 118, 1883-1891. doi:10.1111/j.1600-0706.2009.17643.x

Penhoat, A., Jaillard, C., Saez, J.M., 1989. Corticotropin positively regulates its own receptors and cAMP response in cultured bovine adrenal cells. PNAS 86, 4978-4981.

Preston, J.R., Hoffman, G.R., 2008. Gene toxicology. In: Klaassen, C.D. (Eds.), Casarett and Doull's Toxicology: The Basic Science of Poisons. McGraw Hill, USA.

Rich, E.L., Romero, L.M., 2005. Exposure to chronic stress downregulates corticosterone responses to acute stressors. American Journal of Physiology - Regulatory, Integrative and Comparative Physiology 288, R1628-R1636. doi:10.1152/ajpregu.00484.2004

Romero, L.M., 2004. Physiological stress in ecology: lessons from biomedical research. Trends Ecol. Evol. 19 (5), 249-255.

Romero, L.M., 2012. Using the reactive scope model to understand why stress physiology predicts survival during starvation in Galápagos marine iguanas. General and Comparative Endocrinology 176, 296-299. doi:10.1016/j.ygcen.2011.11.004

Sagerup, K., Helgason, L.B., Polder, A., Strøm, H., Josefsen, T.D., Skåre, J.U., Gabrielsen, G.W., 2009. Persistent organic pollutants and mercury in dead and dying glaucous gulls (Larus hyperboreus) at Bjørnøya (Svalbard). Science of The Total Environment 407, 6009-6016. doi:10.1016/j.scitotenv.2009.08.020

Savinova, T.N., Polder, A., Gabrielsen, G.W., Skaare, J.U., 1995. Chlorinated hydrocarbons in seabirds from the Barents sea area. Sci. Total Environ. 160-161, 497-504.

Schmidt, K.L., Furlonger, A.A., Lapierre, J.M., MacDougall-Shackleton, E.A., MacDougallShackleton, S.A., 2012. Regulation of the HPA axis is related to song complexity and 
measures of phenotypic quality in song sparrows. Hormones and Behavior 61, 652-659. doi:10.1016/j.yhbeh.2012.02.027

Schultner, J., Moe, B., Chastel, O., Bech, C., Kitaysky, A.S., 2014. Migration and stress during reproduction govern telomere dynamics in a seabird. Biol. Lett. 10, 20130889.

Tan, S.W., Meiller, J.C., Mahaffey, K.R., 2009. The endocrine effects of mercury in humans and wildlife. Critical Reviews in Toxicology 39, 228-269. doi:10.1080/10408440802233259

Tartu, S., Goutte, A., Bustamante, P., Angelier, F., Moe, B., Clément-Chastel, C., Bech, C., Gabrielsen, G.W., Bustnes, J.O., Chastel, O., 2013. To breed or not to breed: endocrine response to mercury contamination by an Arctic seabird. Biol. Lett. 9.

Tartu, S., Angelier, F., Herzke, D., Moe, B., Bech, C., Gabrielsen, G.W., Bustnes, J.O., Chastel, O., 2014. The stress of being contaminated? Adrenocortical function and reproduction in relation to persistent organic pollutants in female black legged kittiwakes. Science of The Total Environment 476-477, 553-560. doi:10.1016/j.scitotenv.2014.01.060

Tartu, S., Angelier, F., Wingfield, J.C., Bustamante, P., Labadie, P., Budzinski, H., Weimerskirch, H., Bustnes, J.O., Chastel, O., 2015a. Corticosterone, prolactin and egg neglect behavior in relation to mercury and legacy POPs in a long-lived Antarctic bird. Sci. Total Environ. 505, 180-188.

Tartu, S., Angelier, F., Bustnes, J.O., Moe, B., Hanssen, S.A., Herzke, D., Gabrielsen, G.W., Verboven, N., Verreault, J., Labadie, P., Budzinski, H., Wingfield, J.C., Chastel, O., 2015b. Polychlorinated biphenyl exposure and corticosterone levels in seven polar seabird species. Environ Pollut 197, 173-180.

Tyler, C.R., Jobling, S., Sumpter, J.P., 1998. Endocrine disruption in wildlife: a critical review of the evidence. Crit. Rev. Toxicol. 28, 319-361.

Verboven, N., Verreault, J., Letcher, R.J., Gabrielsen, G.W., Evans, N.P., 2009. Nest temperature and parental behaviour of Arctic-breeding glaucous gulls exposed to persistent organic pollutants. Animal Behaviour 77, 411-418. doi:10.1016/j.anbehav.2008.10.022

Verboven, N., Verreault, J., Letcher, R.J., Gabrielsen, G.W., Evans, N.P., 2010. Adrenocortical function of Arctic-breeding glaucous gulls in relation to persistent organic pollutants. General and Comparative Endocrinology 166, 25-32. doi:10.1016/j.ygcen.2009.11.013

Verreault, J., Gabrielsen, G.W., Bustnes, J.O., 2010. The Svalbard Glaucous Gull as Bioindicator Species in the European Arctic: Insight from 35 Years of Contaminants Research, in: Whitacre, D.M. (Ed.), Reviews of Environmental Contamination and Toxicology Volume 205, Reviews of Environmental Contamination and Toxicology. Springer New York, pp. 77-116.

Wada, H., Cristol, D.A., McNabb, F.M.A., Hopkins, W.A., 2009. Suppressed Adrenocortical Responses and Thyroid Hormone Levels in Birds near a Mercury-Contaminated River. Environ. Sci. Technol. 43, 6031-6038. doi:10.1021/es803707f

Wada, H., Hahn, T.P., Breuner, C.W., 2007. Development of stress reactivity in white-crowned sparrow nestlings: Total corticosterone response increases with age, while free corticosterone response remains low. General and Comparative Endocrinology 150, 405-413. doi:10.1016/j.ygcen.2006.10.002

Wayland, M., Gilchrist, H.G., Marchant, T., Keating, J., Smits, J.E., 2002. Immune Function, Stress Response, and Body Condition in Arctic-Breeding Common Eiders in Relation to Cadmium, Mercury, and Selenium Concentrations. Environmental Research 90, 4760. doi:10.1006/enrs.2002.4384

Weimerskirch, H., Lallemand, J., Martin, J., 2005. Population sex ratio variation in a monogamous long-lived bird, the wandering albatross. Journal of Animal Ecology 74, 285-291. doi:10.1111/j.1365-2656.2005.00922.x 
Wingfield, J., 1994. Modulation of the adrenocortical response to stress in birds. Perspectives in comparative endocrinology 520-528.

Wingfield, J.C., 2013. Ecological processes and the ecology of stress: the impacts of abiotic environmental factors. Funct Ecol 27, 37-44. doi:10.1111/1365-2435.12039

Wingfield, J.C., Sapolsky, R.M., 2003. Reproduction and Resistance to Stress: When and How. Journal of Neuroendocrinology 15, 711-724. doi:10.1046/j.1365-2826.2003.01033.x

Wingfield, J.C., Kelley, J.P., Angelier, F., 2011. What are extreme environmental conditions and how do organisms cope with them? Current Zoology 57. 
Table 1. Concentrations of red blood cells' $\mathrm{Hg}(\mu \mathrm{g} / \mathrm{g} \mathrm{dw})$ and whole blood persistent organic pollutants (pg/g ww) in incubating male black-legged kittiwakes.

\begin{tabular}{|c|c|c|c|c|}
\hline Contaminants & Mean (median) & SD & Minimum & Maximum \\
\hline $\mathrm{Hg}$ & $1.80(1.96)$ & 0.45 & 0.82 & 2.96 \\
\hline РСВ 28 & $224(200)$ & 84 & 50 & 478 \\
\hline PCB 99 & $927(740)$ & 566 & 410 & 2700 \\
\hline РCB 105 & $323(267)$ & 222 & 135 & 1163 \\
\hline РСВ 118 & $1124(930)$ & 731 & 500 & 3870 \\
\hline PCB 138 & $3931(3120)$ & 2865 & 1550 & 14750 \\
\hline РCВ 153 & $4968(3820)$ & 3824 & 1800 & 20280 \\
\hline РCB 180 & $2143(1550)$ & 1648 & 730 & 8490 \\
\hline PCB 183 & $434(325)$ & 336 & 148 & 1759 \\
\hline PCB 187 & $756(591)$ & 519 & 321 & 2529 \\
\hline$\Sigma$ PCBs & $14,831(11,827)$ & 10,694 & 5801 & 55,951 \\
\hline $\mathrm{HCB}$ & $2977(2700)$ & 872 & 1850 & 6400 \\
\hline oxy-Chlordane & $801.6(667)$ & 385 & 359 & 2120 \\
\hline trans-Nonachlor & $38.9(35)$ & 21 & 6 & 98 \\
\hline cis-Nonachlor & $35(32)$ & 16 & 5 & 71 \\
\hline Mirex & $388(352)$ & 198 & 167 & 959 \\
\hline$p, p^{\prime}-\mathrm{DDE}$ & 1265 (1177) & 697 & 306 & 3506 \\
\hline$\Sigma O C P S$ & $4241(3700)$ & 1413 & 2495 & 9616 \\
\hline
\end{tabular}


Table 2. Parameter estimates for generalized linear models (GLM) assessing the relationships between contaminants (Hg, $\sum$ PCBs and $\sum \mathrm{OCPs}$ ) and A) [CORT $\mathrm{BL}_{\mathrm{BL}}$, B) $\left.\mathrm{CORT}_{\mathrm{SI}}, \mathrm{C}\right) \mathrm{CORT}_{\mathrm{DEX}}$ and $\mathrm{D}) \mathrm{CORT}_{\mathrm{ACTH}}$ in incubating male black-legged kittiwakes.

\begin{tabular}{|c|c|c|c|c|c|c|}
\hline $\begin{array}{l}\text { Dependent } \\
\text { variable }\end{array}$ & $\begin{array}{l}\text { Independent } \\
\text { variable }\end{array}$ & Intercept & Estimate & $D f$ & $F$ & $P$-value \\
\hline \multirow{3}{*}{ (A) $\mathrm{CORT}_{\mathrm{BL}}$} & $\mathrm{Hg}$ & 2.07 & -0.33 & 1.28 & 0.81 & 0.376 \\
\hline & $\Sigma$ PCBs & 1.73 & 0.02 & 1.25 & 0.01 & 0.913 \\
\hline & $\Sigma O C P s$ & 6.40 & -0.54 & 1.25 & 2.19 & 0.152 \\
\hline \multirow[t]{3}{*}{ (B) $\mathrm{CORT}_{\mathrm{SI}}$} & $\mathrm{Hg}$ & 3.32 & -0.03 & 1.28 & 0.02 & 0.882 \\
\hline & $\Sigma \mathrm{PCBS}$ & 3.89 & -0.06 & 1.25 & 0.34 & 0.562 \\
\hline & $\Sigma O C P s$ & 3.55 & 0.03 & 1.25 & 0.02 & 0.885 \\
\hline \multirow{3}{*}{ (C) $\mathrm{CORT}_{\mathrm{DEX}}$} & $\mathrm{Hg}$ & -9.81 & 3.52 & 1.28 & 2.38 & 0.134 \\
\hline & $\Sigma$ PCBs & -10.07 & 0.22 & 1.25 & 0.03 & 0.867 \\
\hline & $\Sigma O C P S$ & -26.12 & 2.18 & 1.25 & 0.76 & 0.391 \\
\hline \multirow{3}{*}{ (D) $\mathrm{CORT}_{\mathrm{ACTH}}$} & $\mathrm{Hg}$ & 2.89 & -3.55 & 1.28 & 1.83 & 0.187 \\
\hline & 乏PCBs & -27.10 & 2.96 & 1.25 & 4.68 & 0.040 \\
\hline & $\Sigma O C P s$ & -36.12 & 4.45 & 1.25 & 2.64 & 0.117 \\
\hline
\end{tabular}

Bold values refer to statistically significant relationships $(\mathrm{P}<0.05)$. 

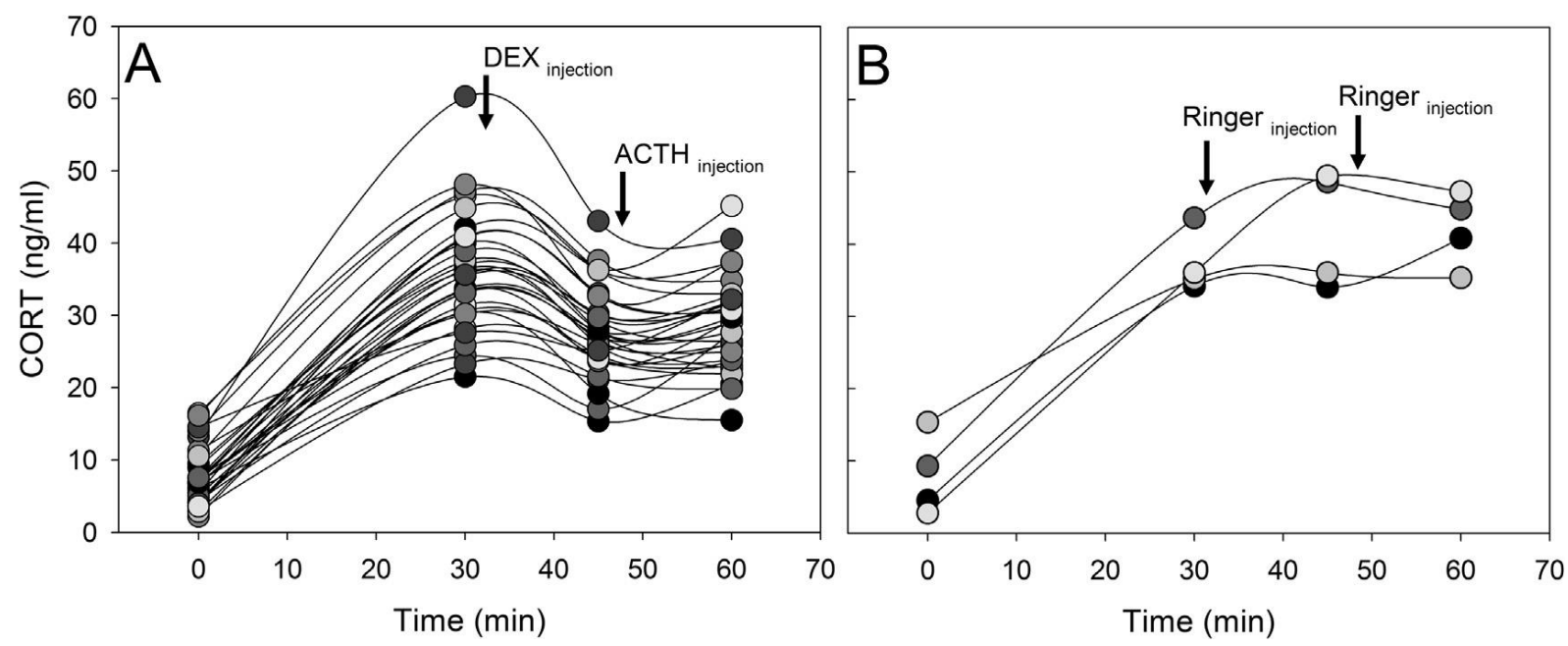

Figure 1. Stress series to characterize the hypothalamo-pituitary-adrenal (HPA) activity in incubating male black-legged kittiwakes. CORT increase from 0 to 30 min indicates the time of exposure to restraint stress. The left panel represents birds that were injected with DEX and ACTH (A) and right panel birds injected with Ringer's physiological solution (B). Each circle denotes an individual and arrows indicate the time of injections. 

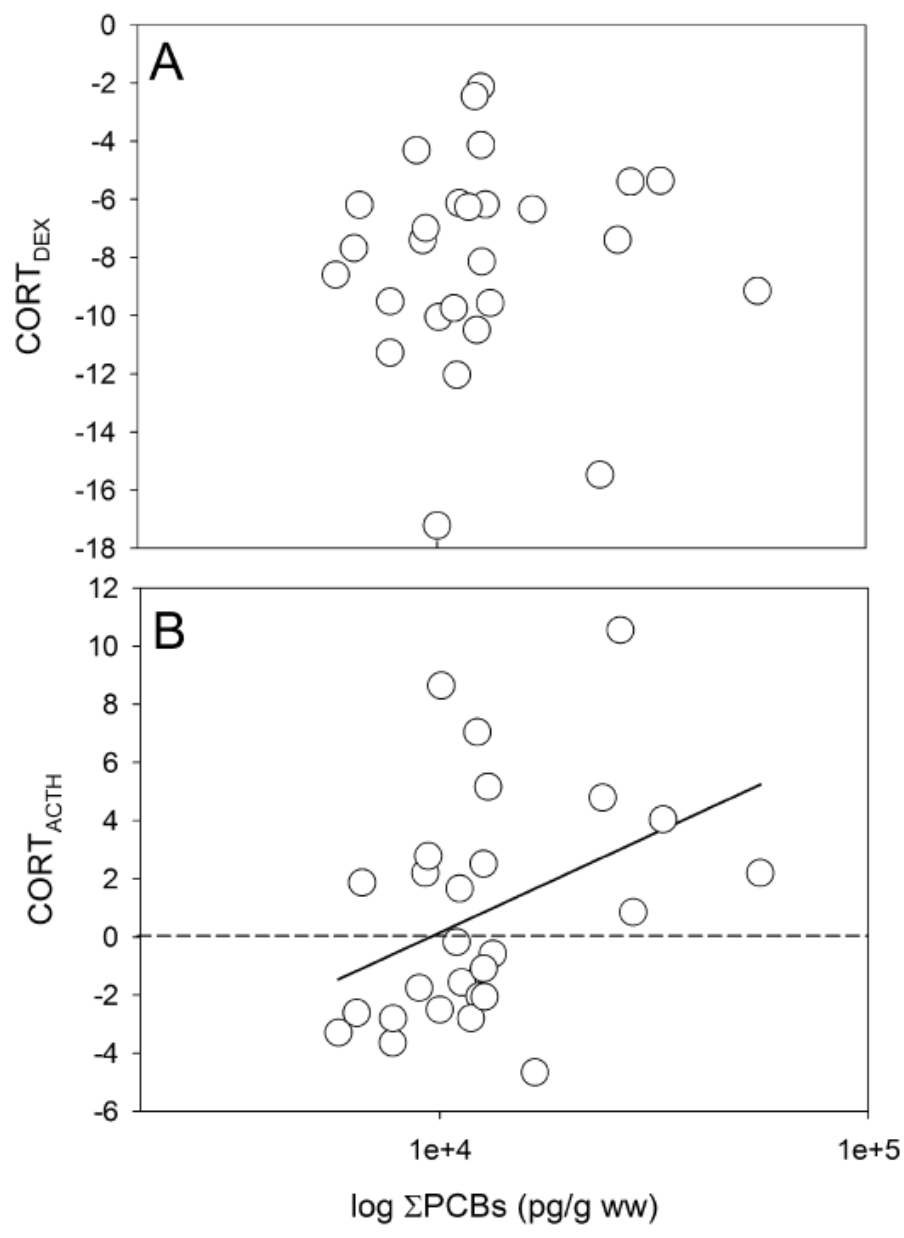

Figure 2. $\mathrm{CORT}_{\mathrm{DEX}}$ and $\mathrm{CORT}_{\mathrm{ACTH}}$ in relation to $\sum \mathrm{PCB}$. In incubating male black-legged

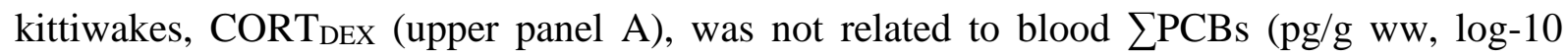
transformed). Whereas $\mathrm{CORT}_{\mathrm{ACTH}}$ (lower panel B), was positively associated with $\sum \mathrm{PCBs}$. ACTH injection elicited an increase of CORT in male kittiwakes above dashed line and a decrease of CORT in individuals below. Solid line refers to significant linear regression $(\mathrm{P}=$ $\left.0.040, \mathrm{R}^{2}=0.16\right)$ 


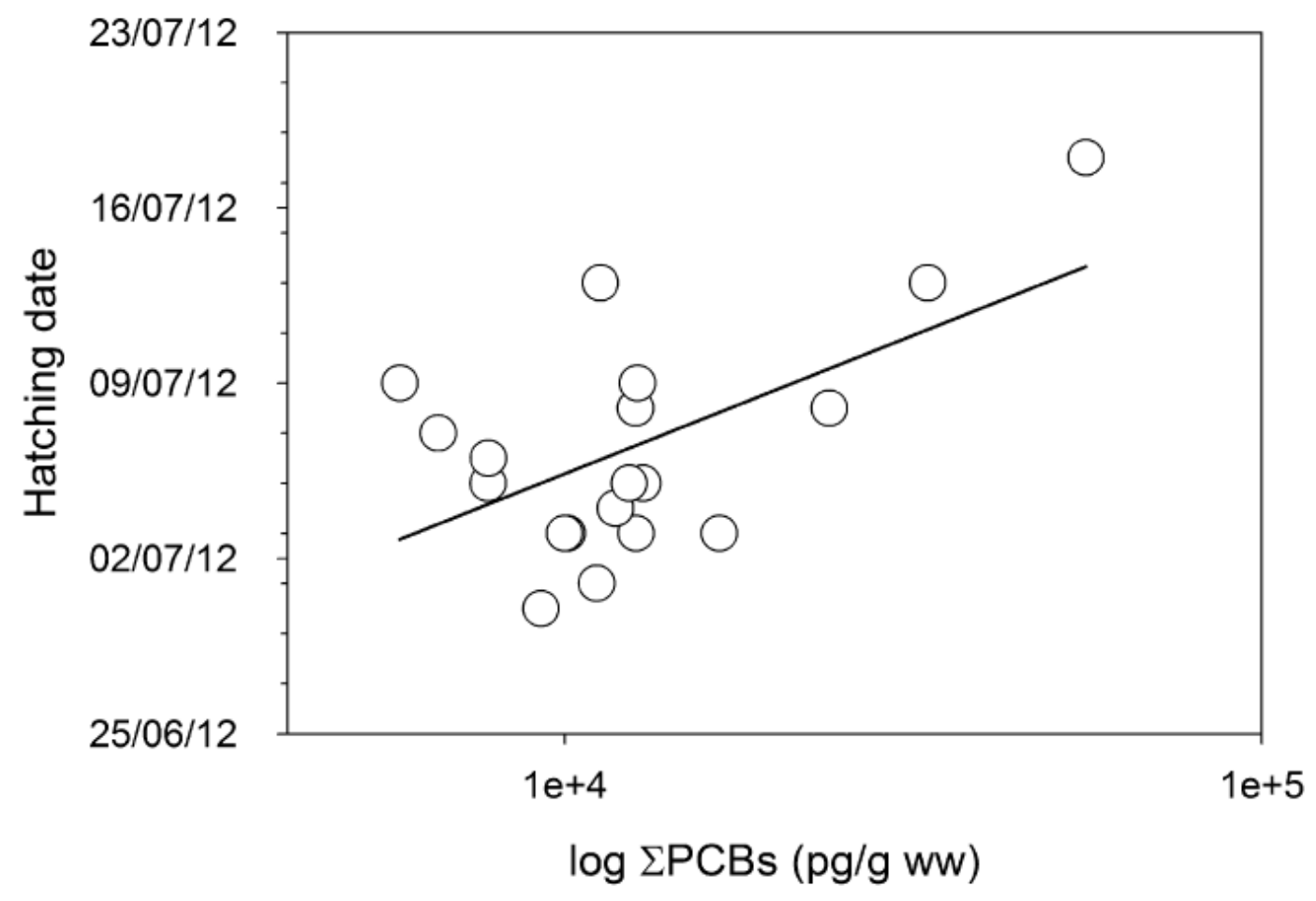

Figure 3. Hatching date in relation to $\sum$ PCBs. In male black-legged kittiwakes increasing blood $\sum$ PCBs (pg/g ww, log-10 transformed) delayed the hatching of the first egg laid. Solid line refers to significant linear regression $\left(\mathrm{P}<0.001, \mathrm{R}^{2}=0.35\right)$. 